\title{
The Tyranny of the Majority: A Case Study of the McCarthy Era
}

\begin{abstract}
Alexis de Tocqueville observed in his travels through the United States in the 1830 s that the system of majoritarian representation could become subject to a 'tyranny of the majority'. This concept exists on the political and the social axis. The tyranny of the majority of the social axis, where majorities impose their viewpoints on minorities and subjugate minorities to their opinion is most extensively analyzed in this chapter. In this, minorities tend to conform to majority opinion out of fear of repercussions. This chapter thus provides a link between the tyranny of the majority and the conformity theory. It researches whether American society has become subject to the tyranny of the majority during the McCarthy era. The main claim derived from this research problem is that American society was indeed subject to the tyranny of the majority during the McCarthy era. Nevertheless, a tension was apparent in society. Although minorities indeed conformed to majority opinion and there was a climate of political intolerance, some minorities were in fact able to turn the conformity theory upside down and influenced the majority in such a way that minority opinion prevailed. This phenomenon was noticeable in the Civil Rights Movement, where African Americans persuaded predominantly white Americans that African Americans should be granted equal rights. In short, American society is highly in flux. Although the tyranny of the majority became a social reality during the McCarthy era, at the same time a minority was able to persuade the majority of its viewpoints.
\end{abstract}

\section{Eva Durlinger ${ }^{1}$}

\footnotetext{
${ }^{1}$ Eva Durlinger received a bachelor degree in European Studies at Maastricht University in 2017. At the moment she takes a Master in European Studies Research at Maastricht University. Contact: evadurlinger@gmail.com
} 


\section{Introduction}

In the system of majoritarian representation followed in the United States of America, claims about the incumbent government only representing the viewpoints of those who voted the established authority into power are of all times. But are these claims grounded? Alexis de Tocqueville (2003) observed in his travels through the United States in the 1830s that the democratic system employed in the US indeed favors majoritarian representation and therefore carries out the wishes of the majority. In light of this, he claims that American society can become subject to a tyranny of the majority. This concept implies that the majority has the ability to tyrannize society with its opinions, and subjugates those holding minority viewpoints to them.

Although Tocqueville made his claim almost two centuries ago, the democratic system of the United States has barely been altered, mostly due to the rigidity of the American Constitution. Consequently, Tocqueville's warning of the tyranny of the majority as applied to America of the 1830 s can still be of value today. Established authors in the field of conformity and political tolerance point toward the McCarthy era as a period of political intolerance where people conformed to majority opinion. Has this period of time, however, also experienced real majoritarian tyranny? This chapter examines exactly this and therefore poses the following research question: Was American society during the McCarthy era subject to the tyranny of the majority?

To answer this research question, it is of utmost importance to provide a clear understanding of Tocqueville's concept of the tyranny of the majority. Therefore, an extensive conceptual analysis of this term is provided first. The conformity theory is linked to Tocqueville's concept to show that the concept is not just a potential threat to democracy but that it has real implications. The concept of political intolerance reinforces the conformity theory and thereby in part explains how the tyranny of the majority can become a social reality in American society. After having established the theoretical groundwork, this chapter examines whether there was a tyranny of the majority during McCarthyism by employing an idiographic theoryguided single case study of the McCarthy era. This implies that I aim to thoroughly investigate one significant episode in history which is not generalizable (Levy, 2008). The case study is divided into two parts. The first part examines the presence of the conformity theory and a politically intolerant society during the time period of McCarthyism (1947-1956). The second part focusses on a subgroup in American society, African Americans, during the same timeframe. The reason for this is that this group exhibits the traits of conformity but more importantly demonstrates minority influence; an occurrence in society where minorities have the ability to persuade the majority of their viewpoints.

This case study was chosen because multiple scholars agree that the conformity theory held during this era (Gibson, 1988; Gibson, 2006; Gibson, 2008; Noelle-Neumann, 1974; Peffley \& Sigelman, 1990), since dissidents were incarcerated based on allegations of adherence to communist ideology. Nevertheless, so far no author has attempted to provide a plausible explanation of this era constituting a tyranny of the majority. Moreover, after having done qualitative research of mostly secondary sources, it became clear 
that during this era when conformity held, the counter theory, the minority influence theory, was also apparent (Lee, 2002; Samad, 2008; Sustar, 2012). For a proper understanding of what is analyzed, operationalization of the concepts of majority and minority is necessary. The term majority refers to those people who hold the same viewpoints, which are shared among the largest number of citizens. Moscovici, Mucci-Faina, and Maass (1994) reason that minorities can be defined as "every group that, for whatever reason, deviates or transgress from the establishment rules or norms, or dissents, that is, thinks differently from most members of the community" (p. 238).

I claim that Tocqueville's tyranny of the majority can be explained by the conformity theory. Since the conformity theory held during the McCarthy era and Tocqueville's concept of majoritarian tyranny can be explained by this theory, America thus has been subject to the tyranny of the majority. Nevertheless, during this same period of time, a powerful minority consisting of African Americans has been able to influence the majority and persuade this majority of their deviant view: that African Americans should have the same rights as white Americans. Therefore, the main claim this chapter poses is that American society is highly in flux and shows two sides of one coin: in an era where the majority tyrannizes those holding deviant thought, minorities also have the ability to convince majorities of their standpoints. This claim is in line with Tocqueville's observation that the majority is an absolute force in society but that it cannot claim omnipotence of it.

\section{The Tyranny of the Majority}

The concept this chapter examines is that of the tyranny of the majority. During his travels through America in the 1830s, Alexis de Tocqueville analyzed the qualities of American democracy. Although Tocqueville saw the democratic system employed in the United States as a better regime in comparison to European aristocracy, he also noted its potential dangers. One of the dangers he observed is that of majoritarian tyranny. According to Tocqueville, the tyranny of the majority is composed of two axes: a political tyranny and a social tyranny. Both axes are explained in detail in the following sections. Most emphasis is placed on the social axis since both Tocqueville and his supporters viewed the social tyranny as the most dangerous to the existence of American democracy.

\subsection{The Political Axis}

One of the most interesting tenets of American democracy, Tocqueville (2003) argued, was the inherent 'equality of social conditions'. Here, "Tocqueville did not refer to the literal material equality of all American citizens, but rather the universal assumption that no significance was to be accorded any apparent differences-material, social, or personal" (Deneen, 2011 , p. 1). Accordingly, the political system was developed in such a way that equality prevailed. In combination with the belief rooted in the Enlightenment that multiple men were more knowledgeable to take decisions than just one, the Americans established a government based on majoritarian representation. Rand (1964) observes that in this democratic system "the government's function was changed from the role of ruler to the role of servant" (p. 91), executing the wishes of the majority. Tocqueville (2003) 
likewise observed that the government represents the general good of the majority, which implies that it does not represent the general good of the population and therefore leaves the minority out of consideration. The government thus carries out the majority's wishes and thereby ignores those of the minority. Tocqueville (2003) reinforces this statement by arguing that:

Since the majority has absolute control over making the law and supervising its execution, and since it has equal control over rulers and ruled, it considers its public officials as its passive agents and is glad to leave them the care of serving its strategies. (p. 296)

Consequently, the main danger Tocqueville (2003) saw in America was not the weakness of the democratic system, but its strength. He claimed that there is no guarantee against the majority, since it rules over public opinion, is represented by the legislature, and appoints the executive. Moreover, Tocqueville (2003) noticed an ever-growing majoritarian populism where the legislature increasingly becomes dominant over the other two branches. Adding to the dangers, the equality of social conditions ensured that citizens held more or less the same views, since they were on equal footing with one another (Tocqueville, 2003). It is exactly this that fosters majority rule according to Tocqueville because the "nation is [not] divided between several great irreconcilable interests" (p. 289). Moreover, due to the similarity and only slight divergence of interests, the minority would over time get used to the majority's wishes and consequently obey, in the hope some day they would constitute the majority (Tocqueville, 2003). This equality of social conditions formed the basis of the political tyranny of the majority.

Nevertheless, Tocqueville (2003) argued, "the majority, which often has despotic tastes and instincts, still lacks the most developed tools of tyranny" (p. 306) since administrative decentralization provides the safeguard against political majoritarian tyranny. Already in 1787, founding father James Madison noted that the Constitution and inherent separation of powers provided a bulwark against a political tyranny from occurring (Madison, 2001a). Similarly, Rand (1964) claimed that "a complex legal system, based on objectively valid principles" (p. 108) is a necessary precondition to prevent a political tyranny. In the US, this was ensured through the constitutionally established checks and balances. However, the same author noted that the Constitution that ensures the system of checks and balances is designed to only limit the powers of government. Individuals are not kept in check by the Constitution and therefore a tyranny by society is not prevented by the governmental system. Similarly, Mill (1882) reasoned, political tyranny, "though a real evil, does not appear to be a formidable one" ( $p .118$ ). Instead, he argued, "the tyranny which we fear, and which $M$. de Tocqueville principally dreads, is of another kind - a tyranny not over the body but over the mind" (p. 118).

\subsection{The Social Axis}

Both Tocqueville and Mill claim that social tyranny is much more dangerous than political tyranny will ever be. James Madison already warned in the "Federalist Papers No. 51" that American society should not only be guarded from oppression by the rulers, but more importantly from oppression of one part of society by the other (Madison, 2001b). According to Tocqueville (2003), the majority simply constitutes a group of individuals that hold opinions and interests that oppose those of the minority. Since an individual 
can use his power against an opponent in an abusive manner, so too can a majority. Mill (2001) shares Tocqueville's view of the tyranny of the majority and reasons that:

Society can and does execute its own mandates: and if it issues wrong mandates instead of right, or any mandates at all in things with which it ought not to meddle, it practices a social tyranny more formidable than many kinds of political oppression, since, though not usually upheld by such extreme penalties, it leaves fewer means of escape, penetrating much more deeply into the details of life, and enslaving the soul itself. (p. 9)

Therefore, Mill (2001) notes, there must not only be safeguards against the tyranny by government, but, more importantly, against social tyranny, because the danger lies in the fact that the majority imposes its ideas on a dissenting minority.

What the majority attempts to do here, Rand (1964) argues, is abolishing individualism and creating only collective thought. In this sense, she claims, "some men (the majority ...) are ethically entitled to pursue any whims (or any atrocities) they desire to pursue, while other men are ethically obliged to spend their lives in the service of that gang's desires" (p. 11). Mousourakis (2014) reasons that Mill saw the same danger of uniformity:

A person may be unimpeded by social or legal constraints and yet ... be dominated by a more subtle and much more effective form of social tyranny: custom, convention and mass opinion may be operating on him in such a way that he never stops to think where or how he acquired his beliefs or desires and it rarely occurs to him to question them. (p. 28)

Mill (2001) notes that Americans do not need to individually think anymore since men like them think for them and impede their thought on them through newspapers. Moreover, Tocqueville (2003) argues "a newspaper survives only if it echoes a doctrine or opinion common to a large number of men" (p. 603). This shows that only majoritarian opinion is reprinted which arouses uniformity. Therefore, Mill (2001) argues, it is important that those individuals that diverge from mass opinion should be encouraged to do so, not deterred.

Tocqueville (2003) additionally claims that "the majority is endowed with a force both physical and moral which affects people's will as much as their actions" (p. 297). This absolute force the majority holds makes for America to be the country where there is the least freedom of thought according to Tocqueville. In aristocratic Europe, authority cannot prevent hostile thought in society. In democratic America, as long as the majority has not formulated its opinion, deviant thought and speech is allowed. When the majority has expressed its verdict, however, the minority is silenced from speaking. Tocqueville moreover observes that Americans accord more importance to equality than to freedom. He claims that Americans "have a burning, insatiable, constant, and invincible passion for equality; they want equality in freedom and, if they cannot have it, they want it in slavery" (Tocqueville, 2003, p. 587).

Consequently, Maletz (2002) reasons that "democratic majorities sometimes configure equality with very significant exclusions, drawing the boundaries of citizenship far more narrowly than the language of equality suggests" (p. 743). The majority has established the boundaries of thought 
and only within those boundaries is the minority allowed to think freely. When someone would publish their writing outside these boundaries, he is withheld by the majority from everything he values in social life, such as renown and a career. Therefore, "a citizen has to abandon to some extent his rights and, so to speak, his very qualities as a man, if he wishes to diverge from the path marked out by the majority" (Tocqueville, 2003, p. 301). Moreover, "it seems he has lost [his supporters] once he has declared himself publicly; for his detractors speak out loudly and those who think as he does, but without his courage, keep silent and slink away" (p. 298).

\section{The Conformity Theory and Political Intolerance}

In accordance with the notion of the tyranny of the majority, and more specifically the social axis, I claim that Solomon Asch's conformity theory in a climate of political intolerance proves that the tyranny of the majority is not just a concept, but a social reality. Asch (1955) reasons that "the same epoch that has witnessed the unprecedented technical extension of communication has also brought into existence the deliberate manipulation of opinion and the "engineering of consent"" (p. 32). This quote implies that the opinion of a certain group is manipulated by a (presumable) majority in such a way that the minority group thinks its own opinion is not valid and therefore consents to majority opinion. Asch reached this conclusion by executing a number of psychological experiments that came to be known as the 'Asch conformity experiments'. Conformity is understood as "a largely implicit psychological process whereby individuals come to believe that group norms are appropriate and, for that reason, bring their beliefs, opinions, and/or behavior into line with them" (Suhay, 2016, p. 3). The sort of conformity this thesis looks at, political conformity "represents those instances when individuals conform to politically relevant group norms, i.e., widely shared beliefs, opinions, and behaviors that relate to the governance of a polity" (p. 3).

In his conformity experiments, Asch assembled a group of seven to nine men to participate in a visual judgement exercise. The group was seated in a classroom and was shown three pictures of lines. Every individual had to say which line matched the length of the line on the other card. In the first two rounds, the entire classroom gave the same response to which line matched the other. From the third round onwards, however, every person but one agreed on which line matched the one on the card. In the next rounds, he remained the only dissenter and Asch observed that this person started to question his observations. What this person did not know was that Asch beforehand instructed all other men but him to give incorrect answers and remain unanimous in providing these answers. Asch conducted eighteen of such experiments. He observed that "whereas in ordinary circumstances individuals matching the lines will make mistakes less than 1 per cent of the time, under group pressure the minority subjects swung to acceptance of the misleading majority's wrong judgments in 36.8 percent of the selections" (Asch, 1955, p. 33-34).

Undeniably, participants differed in response. Some never complied with the majority opinion whereas others conformed constantly. To understand the discrepancy among respondents, Asch held individual 
meetings with them. He found out that those who did not follow the majority either did so because they were firmly convinced of their own viewpoints or because they did believe the majority was correct but wanted to give a deviant opinion. Those who did conform to the majority soon came to believe that they ought to have been wrong and the majority must have been right and therefore merged with the majority's opinion. The main conclusion that can be derived from Asch's experiment is that "confronted with opinions contrary to their own, many subjects apparently shifted their judgments in the direction of the views of the majorities" (Asch, 1955, p. 33). Suhay (2015) noticed that individuals tend to comply with the majority's opinion even when the majority does not provide any arguments or explanations for its viewpoints. Asch (1955) similarly observed that the numerical authority of the majority sufficed to persuade individuals holding minority viewpoints, even when no arguments for the majority opinion were given. The size of the majority, nevertheless, is only of importance up to some point. People tend to conform more quickly when up to three opponents share a contrary opinion. The tendency to conform stagnates when a larger number shares a distinct viewpoint. What carries more weight is the unanimity of the majority (Asch, 1955).

Deutsch and Gerard (1955) claim that the social conformity observable in Asch's experiments can be attributed to two types of influence: normative and informational. In the latter, the minority is persuaded by the majority and holds the majority's opinion to be correct.

In the former, the minority conforms to the majority's opinion in an attempt to 'fit in' and not be an outsider. Conformists therefore do not necessarily believe the majority's opinion is correct and only in public they adhere to it. In private, their deviant thought prevails. Suhay (2016) reasons that "failing to abide by common behavioral norms is particularly uncomfortable for people, typically causing anxiety, embarrassment, guilt, and/or shame" (p.13) because it is felt that peers refute derogation, while "adhering to norms is less eventful emotionally but can foster feelings of well-being and pride" (p. 13) because there is a perception of peer admiration. This implies that individuals are unwary not to conform because they fear repercussions. This is what Tocqueville warned about: those holding majority opinion subjugating the minority to this opinion and otherwise excluding individuals from social life. Especially when one belongs to a certain group or community the feelings of embarrassment in the case of deviant opinion or pride in the case of adhering to majority opinion are encountered (Suhay, 2016, p. 13). These feelings increase when there is a perception of a politically intolerant society.

Political tolerance "involves the conviction that those who vote for political parties that one does not like, or who are members of organizations to which one objects, should nonetheless have the same rights as oneself" (Widmalm, 2013, p. 295). This includes granting people with distinct viewpoints the same opportunities in politics. Gibson (2006) asserts, in line with Tocqueville, that one of the most important characteristics of democracy is that everyone has the opportunity to someday constitute the majority. To have this opportunity, citizens must thus all have equal rights to formulate their opinions, to express their opinions to the incumbent government and to fellow citizens, and to have their opinions taken into account on the same basis as other opinions are (Gibson, 2006, p. 23). When this is denied, the basic tenets of (American) democracy are lost. 
A politically intolerant society refuses to grant individuals holding diverging opinions equal rights and opportunities. They especially refuse to give deviant thinkers freedom of speech, which hampers dissidents from expressing their viewpoints, something Tocqueville already warned about in the 1830s. In Tocquevillian terms, the majority thus suppresses minority rights and opportunities and tyrannizes society by subjugating the minority to majority viewpoints. The root of political intolerance lies in the perception of threat. This is threat not directed at the individual, but at the country. The more there is a perceived threat, the more intolerant society will be (Widmalm, 2013). When you perceive someone or a group as a threat, why would you be willing to grant that person or group the same rights as you have?

Gibson (1992) explains that, just like Tocqueville's majoritarian tyranny, political intolerance consists of two axes. The first axis concerns external censorship on deviance by representative institutions. Citizens may feel they are not able to express their views due to limitations imposed on their freedom of speech by the state. Gibson (2011) notes that "many fear that the government, typically under the guise of regulation, will usurp power and deny the expression of ideas threatening to the status quo" (p. 114). The second axis concerns internal censorship by fellow citizens. Widmalm (2013) asserts that the political axis is not as important and that to gain a full comprehension of conflict within democratic society, the social axis is of greater importance. Family, friends or acquaintances may impose sanctions on deviance and may pressure dissidents to conform to majority opinion, as was already seen in the conformity theory. When disagreement is discouraged and deviant opinions are sanctioned, individuals' freedom to express their opinions are severely hampered.

In line with Tocqueville's fear of the emergence of political homogeneity that would eradicate all dissident thought, Gibson (1992) reasons that "political homogeneity in social networks reinforces political intolerance" (p. 122). The equality of social conditions that Tocqueville ascribes to be a threat to political heterogeneity consequently constitutes a threat to political tolerance. This again reinforces majoritarian tyranny since political homogeneity lessens the respect for nonconformity and may result in repercussions for people holding deviant viewpoints (Gibson, 1992, p. 339). Noelle-Neumann similarly argues that public opinion forces people to comply or otherwise be socially isolated (Noelle-Neumann, 1974, p. 44). This fear of isolation and the fact that repercussions may occur for dissidents could result in what she calls a 'spiral of silence'. This constitutes a process in

which those holding minority viewpoints are fearful of expression since they perceive their own views as unusual, which in turns leads to silence, which makes minority viewpoints even less commonly voiced, which in turns leads to silence, and so on. (Gibson, 2008, p. 107)

The political homogenous society will again increase this spiral of silence since the equality of social conditions ensures that people only encounter people that think like them and therefore there is an unawareness of solid arguments for other opinions. People thus fail to see that there are two sides to a coin and that both sides can be supported with legitimate arguments (Gibson, 2008 , p. 98). A homogenous society therefore reinforces the consequences of 
intolerance to a much larger extent than public policy could do (Gibson, 1988, p. 512).

In short, Tocqueville's concept of the tyranny of the majority can be explained by the conformity theory when a political climate of intolerance exists. Whenever a majority group is unwary of granting equal opportunities to people who hold different opinions, it can be said a climate of political intolerance exists. The minority feels repressed because it is unable to speak its mind without being exposed to repercussions, which can be in the form of social exclusion. The majority thus subjugates the minority and creates a society in which the tyranny of the majority persists. The next section explains the linkage of the three previously explained concepts in the McCarthy era. It first establishes that America was rather politically intolerant during this time. Hereafter, it shows that due to this intolerance, people felt the need to conform to majority opinion.

\section{The McCarthy Era as a Tyranny of the Majority}

The period in which Senator McCarthy terrorized Americans with his witchhunts targeted at Communists is considered to be one of the most prominent examples of intolerance and repression in the US (Gibson, 1988; Gibson, 2006; Gibson, 2008; Peffley \& Sigelman, 1990). This period, which came to be known as the Second Red Scare ${ }^{2}$, started when tensions heightened between the United States and the Soviet Union. Fear for war turned into a perception of threat that Communists tried to penetrate into American values. The height of the Second Red Scare was reached in the 1950s when Senator Joseph McCarthy claimed that the US government was infected with Communist-affiliates. Even though his claims were ungrounded, it added to citizens' fear of Communism and initiated the program that started the investigation into people's lives to research possible links with communist organizations (Norton et al., 2012). Norton et al. argue that this "fear spilled over into anticommunist demagoguery and witch-hunts, which trampled civil liberties, suppressed dissent, and resulted in the persecution of thousands of innocent Americans" (p. 764).

Samuel A. Stouffer was the first to research political repression during the McCarthy era on a large scale. Stouffer carried out a tolerance study under about 5000 American respondents. His subjects needed to answer questions that are now referred to as 'standard Stouffer questions' (Widmalm, 2013). In these surveys, people had to:

mention a group which is well-known to be disliked, or to let respondents select such a group, and then to ask a number of questions designed to gauge the extent to which respondents are willing to grant rights to members of that group. (p. 299)

The results were astounding: of 4,933 interviewees, 113 people, only 2.3 percent, claimed to grant Communists equal rights in the political spectrum (Gibson, 2011).

\footnotetext{
${ }^{2}$ The First Red was marked by fear of spread of Bolshevism after the 1917 Russian Revolution (Norton et al., 2012).
} 
Stouffer thus observed widespread political intolerance during the McCarthy era. One of the conclusions of Stouffer's research was that American society was in a state of 'focused intolerance', where intolerance is targeted against a specific group, in this case Communists. This contrasts with 'pluralistic intolerance' in which intolerance is widespread and not directed against one specific group (Peffley \& sigelman, 1990). Sullivan, Piereson, and Marcus (1982) claim that pluralistic intolerance can ensure intolerance fades away. When there is no agreement on what group to target, there is a smaller chance of political repression to occur. Focused intolerance lies at the other end of the spectrum and is directed only against one group in such a way that political repression results. The majority again refuses to grant dissidents equal opportunities and thereby subjugates the minority to its opinions, creating majoritarian tyranny.

This focused intolerance of the 1950s happened on both the politicaland the social axis. On the political axis,

a host of actions against Communists was taken by the states, including disqualifying them from public employment (including from teaching positions in public schools); denying them access to the ballot as candidates, and prohibiting them from serving in public office even if legally elected; requiring Communists to register with the government; and outright bans on the Party. (Gibson, 1988, p. 513)

Estimations have been made that about 13 million people in the workforce of 65 million had been affected by McCarthyism. About 11 thousand people were fired and about 100 were convicted under McCarthy-initiated anticommunism programs. Professors teaching at universities were especially affected by the programs. These were replaced with professors that held no deviant views. Nevertheless, Stouffer's research refuted the widely-held belief that people were brainwashed during the McCarthy era (Gibson, 1988). Moreover, Gibson notes, "in recognizing the coercive power of the state and its willingness to direct that power against those who dissent, the effect of repressive public policy extends far beyond the target group" ( $p$ 516). People who were thus not Communist-affiliated but simply held deviant views than the status quo allowed, also experienced repression. Berg (2007) claims that McCarthyism "blurred the distinction between dissent and treason" (p. 75). Dissidents therefore most probably employed normative conformity: they ensured they conformed to the majority opinion in public, since people informed the authorities about communist suspects, but kept their deviant thought in private.

On the social axis, tolerance was also very widespread. Peffley and Sigelman (1990), who also conducted research on intolerance during the McCarthy era, show that two-thirds of the individuals that were polled indicated that books written by Communists needed to be banned from libraries and that Communists should not have the right to free speech. Nine out of ten people polled indicated that they preferred having alleged Communists fired from schools. The scholars additionally found out that people were not intolerant because of fear of subversion, but because people simply stuck to their own opinions and refused to take deviant views into account. American propaganda in the form of pamphlets, newspaper articles and the McCarthy hearings that aired on television exacerbated the creation of a homogenous society. This society that homogenized and constituted the 
majority sought to eradicate equal opportunities for those holding deviant views, creating a tyranny of the majority. Therefore, the focused intolerance apparent in American society resulted in people fearing to express deviant opinion and thereby created the Silent Generation of the 1950s (Gibson, 2006). As Gibson (2011) claims:

perhaps the most significant legacy of McCarthyism in the United States was not the limitations imposed on Communists and their fellow travelers-legal limitations that were often severe and included imprisonment-but instead was the creation of a "Silent Generation," a cohort unwilling to express views that might be considered controversial or unpopular. (p. 114)

Therefore, on the social axis, people also applied normative conformity. When people would express their deviant opinion, they would experience exclusion from society. There thus was a tyranny of the majority apparent in American society, since people who held deviant viewpoints would experience repercussions and be withheld from equal opportunities when they would express their distinct opinions. In fear of repercussions, they therefore conformed to majority opinion.

\section{Civil Rights Movement under the Minority Influence Theory}

The previous section established that during the McCarthy era American society was tyrannized by majority opinion. Nevertheless, Tocqueville (2003) did not believe majoritarian tyranny would be everlasting and thereby eradicate all deviant thinkers, considering he said that: "I do not deny that one day the Americans may restrict the sphere of political rights, but I cannot believe that they will ever entrust exclusive control to one particular class of citizens" (p. 469). This claim gains more ground when we turn to the Civil Rights Movement in the United States that emerged at the same time McCarthyism prevailed. This movement consisted of an established minority of African Americans that strove for equal rights. Although Tocqueville spoke of the equality of social conditions he found so striking in American society, African Americans were no real part of this. For example, Tocqueville (2003) claims that in the 1830s "voting rights have been granted to the Negro but, if he comes forward to vote, he risks his life" (p. 402). This proves to be another example of Tocqueville's tyranny of the majority since although equality is propagated, freedom to act by the deviating minority is severely restricted by the majority.

It is exactly this that the Civil Rights Movement of the 1950 s sought to eradicate, and succeeded to abolish. The National Association for the Advancement of Colored People (NAACP) that represented this movement gained so much ground that it was able to influence the established majority that was predominantly white and that opposed granting African Americans equal rights (Norton et al., 2012). This movement shows that not only the majority has the ability to ensure people take their viewpoints as the truth but that the minority also has the possibility and the authority to persuade the majority to accept their opinion. Nemeth (2010) reinforces this claim by stating that "minorities were not simply passive agents who either resisted or 
conformed to majority judgments; they could in fact exercise influence themselves" ( $p .7$ ). This phenomenon is explained by the conversion or minority influence theory and is the counterpart of the conformity theory. Moscovici and Personnaz (1980) define conversion as "a subtle process of perceptual or cognitive modification by which a person gives up his/her usual response in order to adopt another view or response, without necessarily being aware of the change or forced to make it" (p. 271).

Sergei Moscovici was the first to propose this theory. He reasoned that too much emphasis within the field of social influence was put on majority power and subsequent conformity. As a starting point for the development of his research he took Deutsch and Gerard's (1955) observation that people conform in two ways: either on both the public and the private level or only on the public level, keeping deviant viewpoints in the private sphere. Moscovici (1980) focused on the latter and conducted subsequent conversion experiments. An explanation of these experiments goes beyond the scope of this chapter considering the vast number and distinctions. Nevertheless, the conclusions derived from these experiments are of importance to this research.

Moscovici (1980) argued that resistance occurs when the minority refuses to agree but out of fear of repercussions, they only keep their resistance in private. Since deviant thought only remains on the private level, this is also where minority influence starts and where it has most impact. Majority influence happens on the public level and has most impact here (Moscovici \& Personnaz, 1980). In an explanation as to why minorities tend to only be influential on the private level from the onset, a link can be drawn to the conformity theory. During social interaction, the majority is unwary of adopting the minority opinion as it would then openly refute the majority viewpoint and adopt a diverging opinion (Moscovici \& Personnaz, 1980). In fear of repercussions, individuals only privately accept the minority viewpoints. As is the case with the conformity theory, people desire to belong and this sense is lost upon deviance from majority opinion. Moreover, when one belongs to a certain group or community, rejection or repercussions are even more likely to occur and more harmful as one could be excluded from social life. Therefore, people are even more reluctant to adhere to minority opinion (Nemeth, 2010). Moscovici (1980) subsequently reasons that "an isolated individual tends to offer resistance, while individuals explicitly belonging to a group tend to conform" (p. 230). Reciprocal ignorance is the biggest pitfall. Here, a member of a group fears to express his deviant opinion without knowing that other group members share this deviant opinion in private. No group member then expresses his opinion out of fear. Only a courageous person dares to express his diverging thought which results in more individuals expressing their opinion (Moscovici, 1980).

The previous section explained that people blindly conform to majority opinion. In the case of minority influence, this is different. Moscovici and Personnaz (1980) argue that "a minority is immediately considered as illegitimate, wrong, or contrary to common sense or reality" (p. 271). Whereas majorities are mostly liked, minorities are most of the time disliked (Moscovici, 1980, p. 236). Both competence and social favorability therefore do not account for a minority to persuade people of their deviant thought. Minorities thus have to put in much more effort to persuade an individual of their opinion than a majority needs. Only after much persistence and 
consistence does an individual that belongs to the majority camp start a validation process to analyze the deviant opinion and consider it may contain some truth (Moscovici \& Personnaz, 1980; Nemeth, 2010). Unlike majorities, minorities need to provide detailed information and additional arguments for their viewpoints. The minority opinion is thus constantly subject to criticism (Maas \& Clark, 1986; Moscovici, 1980; Nemeth, 2010). Notwithstanding, when the minority is consistent and increases in number, its viewpoints become more difficult to oppose since considering more people share the same view, it must be objective and it must contain truth. A person then only dares to speak his private mind in public when the minority has provided sufficient arguments for its opinion and more people tend to share this opinion (Moscovici \& Personnaz, 1980). Then, "in the course of these criticisms and discussions, some of the minority's adversaries might be converted" (Moscovici, 1980, p. 215). Similar to the fact that the unanimity of the majority is of great importance for people to conform, the unanimity of the minority is also important for the minority to persuade individuals of their deviant viewpoints. If only one person distorts this unanimity, the minority loses its credibility (Felps, Mitchell \& Byington, 2006).

Maass and Clark (1986) argue that in an era of conformity, minorities only tend to convert to minority opinion when minority influence is apparent, and only in private. When a powerful minority is absent, it is shown that people conform to majority opinion in both public and private. During the Civil Rights Movement, the minority was very apparent. African Americans ensured they were seen and heard through marches, radio stations and court hearings (Norton et al., 2012). As previously established, not only Communists were repressed during the McCarthy era, but also all dissident thinkers. Therefore, African Americans who struggled for equal rights experienced repercussions on top of 'regular' repercussions they experienced for being black. The Civil Rights Movement, moreover, had close ties with the US Communist Party. In the Soviet Union, racial prejudices were inexistent and therefore it was the Communist Party that aided the Civil Rights Movement in achieving its goal of the abolishment of racial inequality (Norton et al., 2012).

In addition to being targeted for deviant opinion, the Civil Rights Movement also suffered from allegations of Communist infiltration from the mid-1940s onwards (Berg, 2007; Sustar, 2012). "The NAACP sharply protested, but during the heyday of the red scare in the late forties and early fifties, the association's leaders felt compelled constantly to show off its anticommunist credentials" (Berg, 2007, p. 88). The NAACP reasoned that this would halt the advancement of rights of coloured people and therefore "denied all charges that it was dominated by Communists and distanced itself from all groups and individuals suspected of Communist affiliations" (p. 76). In a way, the Civil Rights Movement thus aided the era of conformity and decided to conform to majority opinion that Communists infiltrated American values. Due to an extreme loss in amount of members, "in the late 1940s the NAACP had every reason not to jeopardize its organizational strength further by allowing itself to be publicly associated with Communism." (p. 93). The NAACP therefore reasoned that the Communists did not truly seek the advancement of the rights of African Americans but only exploited the racial issue in an attempt to weaken the US government and to advance the Soviet Union's interests (Berg, 2007). Nevertheless, "the party practiced racial egalitarianism more fully than any other majority-white group in American 
society" (p. 94). From a negative viewpoint, this just looks like an example of American hypocrisy at its finest: although fighting for equal rights for coloured people, "the association kept a roaring silence on the violations of the civil rights and liberties of Communists" (p. 95).

Regardless, African Americans did constitute a powerful minority that was able to convince the majority of their deviant opinion. African Americans shared the same values as the majority and used these values to achieve sympathy. Although Tocqueville (2003) claimed that the homogeneity of society only aided majoritarian tyranny, it can be reasoned that this homogeneity also benefited minority influence, since similar norms ensured people could be persuaded to take deviant viewpoints into account. Samad (2008) provides the example of "King [comparing] students to abolitionists and [drawing] a connection between African-American protests and the Boston Tea Party" (p. 11). In addition, he argues that "African-American nonviolent protesters swayed American public opinion to their side, which led the federal government to undertake political action" (p. 10). African American rhetoric thus consisted of persuading the majority of their opinion through a policy of non-violence. This implies that the struggle for equal rights was achieved not through means of force but through converting public opinion and persuading white supremacists.

More importantly, public opinion as a whole was converted, since those whites that were 'neutral' constituted a larger part of society and would have more impact on public policy changes, something especially important in a democratic country. The policy of non-violence in combination with dramatization was used by African Americans to portray themselves as victims and thereby gain sympathy (Samad, 2008). Moreover, Samad argues, the NAACP "applied a depersonalized conflict rhetoric which means that instead of targeting segregationists in public, non-violent leaders focused on segregation itself as evil" (p. 11). Although it took another decade until the legal elimination of racial inequality in the Civil Rights Act of 1964, African Americans had been able to convince the majority already during the McCarthy era that it deserved equal rights (Norton et al., 2012).

What can be concluded from the above provided analysis is that during the 1950s there was a simultaneity of majority and minority influence. Majority influence mainly happened on the public level while minority influence had most impact on the private level and it took some time to develop it on the public level. American society is thus highly in flux, and although society was subjugated to majority opinion, the minority was able to gather and influence the majority. Although the tyranny of the majority proved to be a reality to American democracy in the McCarthy era, the nature of American society ensured that at the other end, the minority influence theory prevailed. This thus proves Tocqueville's claim that American society is not strong enough to develop into a full majoritarian tyranny.

\section{Conclusion}

This chapter provided an in-depth examination of Alexis de Tocqueville's concept of the tyranny of the majority in the United States. It has first asserted that Tocqueville viewed this concept as having two cornerstones: it consisted of both a political- and a social axis. Together with other prominent 
authors such as Mill, Tocqueville reasoned that a tyranny of the political axis could not become a social reality since the checks and balances inherent in the United States Constitution provided sufficient safeguards. The social axis was thus considered the most important of the two and also the most threatening to the existence of American democracy. When there would be a tyranny of the majority on the social axis, those holding the majority viewpoint would constrain those holding deviant opinions and refuse them the freedoms and opportunities the majority holds. Although Tocqueville developed this concept in the 1830s, this chapter showed that it was a social reality during the 1950 s of the previous century.

This chapter additionally provided a link between the conformity theory and political intolerance, and the tyranny of the majority. The conformity theory established that people with deviant viewpoints changed to majority opinion, mostly only in public, out of fear of repercussions. This was also what Tocqueville warned about in his tyranny of the majority: that the majority would exclude those with deviant viewpoints from social life. Conformity especially happens when there is a politically intolerant society and those that constitute the majority refuse to grant those holding the minority opinion equal rights in the political and social spectrum. As a case study of these concepts, the McCarthy era was chosen. Many prominent authors, such as Gibson, already claimed that during this era conformity was the rule rather than the exception. Not only Communists were severely repressed from participating in American public life, but everyone holding deviant viewpoints experienced repercussions. Therefore, a link can be drawn between the conformity theory in a climate of political intolerance and the tyranny of the majority. This chapter is the first to have established this link between the tyranny of the majority and the conformity theory. Therefore, additional research is needed to provide additional insights into the workings of this connection.

Although this era thus constituted a tyranny of the majority, it also gave way to the counterpart of the conformity theory: the minority influence theory. This theory holds that not only a majority is able to have the minority conform to its opinion, but a minority is likewise able to influence the majority in such a way that it converts to minority opinion. It must be kept in mind, although, that this minority influence constitutes a longer process than conformity. Minorities must first persuade people on the private level before multiple people gain the courage to speak out the minority standpoint, and for influence to take root in the majority's minds. This was the case during the American Civil Rights Movement in which African Americans struggled for equal rights. The NAACP had previous links with the Communist Party of the United States but when the witch-hunts started, it did not want to be affiliated with the party anymore out of fear that the advancement of black rights would be hampered. In this, it aided to conformity, but at the same time it still constituted a minority who was able to persuade the majority to grant equal rights to colored people.

The research question this chapter posed was: Was the McCarthy era subject to the tyranny of the majority? It concludes that there indeed was a tyranny of the majority during the McCarthy era, but that this was not the only force apparent in society, since the established minority of African Americans was also able to persuade the majority of their deviant viewpoints. It was thus shown that there is a tension apparent in American society; a 
tension already indicated by Alexis de Tocqueville. Tocqueville claimed in the 1830 s that a full majoritarian tyranny was not possible: although he did see the threat of majoritarian tyranny, he did not claim that this would be the only force apparent in American society. Tocqueville was correct in assuming that a tyranny of the majority could become a social reality, but could not become all-powerful and solely dominate society. This chapter has shown the exact same: that the majority is a powerful force in society which has the capability to have the minority conform to its viewpoints but at the same time the minority has the power to persuade the majority of its opinion.

The most important limitation of this chapter is the case study used. Even though the idiographic theory-guided case study implies that it is not generalizable to other time periods, the time of writing of this chapter may prove otherwise. Although a comprehensive analysis of the situation of contemporary America is beyond the scope of this chapter, it is worthwhile to assert some tentative conclusions. Donald Trump is President of the United States and his election is not uncontested. Since the terrorist attacks of September 11, 2001, intolerance has increased (Gibson, 2008). When anxiety rose, public policy responded by constraining civil liberties of some. Even though civil liberties have not yet been restrained as heavily as during the McCarthy era, "the American government decided it wise to trade a bit of individual liberty for greater public security, and most Americans support or do not oppose this strategy" (Gibson, 2006, p. 23). Although freedom is restricted to some extent, there are no indications of majoritarian tyranny observable yet. Nevertheless, Trump has used fear for terrorist attacks to his political advantage. Instead of Communists being the bogeymen, Muslims are now targeted. When this fear gets widespread and political intolerance results, a majoritarian tyranny is likely to occur - again. 